The Geographical Journal of Nepal

Vol. 13: 185-200, 2020

Doi: http://doi.org/10.3126/gjn.v13i0.28158

Central Department of Geography,

Tribhuvan University, Kathmandu, Nepal

\title{
Dimensions of land use change and implications in spatial planning of emerging town Bedkot municipality, Kanchanpur district, Nepal
}

\author{
Kedar Dahal* and Krishna Prasad Timalsina \\ Tri-chandrta Multiple Campus, Tribhuvan University
}

(*Corrsponding Author: kedar.geog@gmail.com)

Received: 18 November 2019; Accepted: 12 January 2020; Published: March 2020

\begin{abstract}
Rapid transformation of rural settlements into municipalities in Nepal has brought significant changes in land use and urban expansion patterns mostly through the conversion of agriculture land into the built up area. The issue is studied taking a case of rapidly growing Tarai town of Bedkot Municipality of Kanchanpur District. This study is based on field interaction, observation, and available data review. After the declaration of Bedkot as a municipality, several new roads have been opened and upgraded; and the municipality is well connected to the national transportation network. After promulgated the Constitution of Nepal, 2015 and activated the elected local body, the municipality budget has been increased significantly as a result of increasing municipal investment on socio-economic and physical infrastructure development and environmental protection which have attracted people, goods and services creating it as the zone of influence of the surroundings. Rapid spatial changes have been observed with inflow of population in the municipality. One of the changes found is the increasing built-up area by 3.6 percent and expansion of urban area through decreasing the agriculture land by 3.5 percent. Urban growth has been observed taking place along the highway corridor clustering at nodal junctions and some other potential locations. Implications of such spatial dimensions have been core issue of urban development planning in most of the newly declared municipalities in Nepal.
\end{abstract}

Keywords: land use, urban expansion, built-up area, spatial planning, urban development 


\section{Introduction}

With more than $64 \%$ of urban population in Nepal, it is one of the fastest urbanizing country in the world (World Bank, 2013). The urban growth rate was observed 6\% per year since 1970s (UNDESA, 2012 cited in World Bank, 2013). Latest national population census shows that urban population has increased at the rate of $3.4 \%$ per year in the decade period between 2001 and 2011 (CBS, 2011). The government of Nepal has reclassified many rural areas into urban (municipality) area, which is becoming an important pull factor of urban growth in Nepal; such conversion of rural area into urban one is an important contributor to urban growth in Nepal. In the context of rapid urbanization, the study of spatial expansion of urban growth is very important in the recent years. Urbanization process is playing a significant role in modifying the use of land, and changes over time. Many small market centers are emerging along the main highways, road corridors and nodal junctions which have been a powerful force of inmigration to the peripheral population. Many people are still willing to travel longer distance and tend to settle in urban area to search better employment and education opportunities; therefore, urban areas are becoming more common destinations (World Bank, 2013). This shows that the use of agriculture land in the urban area has been rapidly converted into diversified urban uses (IUDP, 2017; Dahal and Timalsina, 2018).

UN (1974) has discussed urban growth as increase of population of any town or city which can be due to natural increase, rural-urban migration or reclassification of rural settlement into towns or cities (Arshad et al., 2017). Except of population, economic and technological development can also cause urban growth (Pham et al., 2011). However, roads and transportation facilities, public services and utilities and other anthropogenic factors are of course responsible contributor to shape urban growth direction and changes in land use. These all have been triggered to change in spatial dimensions of urban growth.

Most of the urban areas/municipalities in Nepal have rural characters and have agriculture as the main sources of income and employment. But with the declaration of municipalities, urban built-up area is also increasing with increasing population and urban functions in most of the municipalities in Nepal. However, these built up areas in most urban settlements/municipalities are haphazard and unregulated. The haphazard urban growth has led to irregular, substandard and inaccessible housing patterns and significantly increased vulnerability to disaster (World Bank, 2013). This implies to important need of plan intervention to regulate haphazard urban growth and develop a livable urban area in Nepal. 
There has been growing interest in study of land use and land cover changes among the urban planners, development professionals in the recent years particularly after adaptation of federal structure of Nepal. However, newly emerging municipalities located in the Tarai region like Bedkot have important implications of urban transformation which has not been studied much. This study, therefore will be important to look at urban transformation and change in land use in the context of current federal structure of Nepal.

Bedkot Municipality is one of the newly emerging municipalities in Nepal. Urbanization in Bedkot is growing at a very fast rate of approximately $4.4 \%$ per annum. Concerning to the rapid urbanization in the municipality, inadequate urban infrastructure, environmental deterioration, forest encroachment, unplanned urban development, poor housing and squatter settlements, rapid land use change, pressure on agriculture land and poor capacity of institution are some of the core planning issues. In light of these emerging urban development issues for the newly declared municipalities, this paper only covers the land use change and urban growth scenario with spatial dimensions. Therefore, the main objective of this study is to discuss land use changes over a decade and its implication in spatial planning in newly emerging town of Bedkot locating in far western Tarai of Nepal based on GIS analysis, consultations with local stakeholders and field observation.

\section{The study area}

Bedkot is a religious site of Nepal which was declared municipality in 2015. It is located in the Far-West province, Kanchanpur District, bordered with Dadeldhura District to the North, Bhimdutta Municipality to the south and west, and Suklaphanta National Park to the east and south (Figure 1). Sirsaiya, Lalpur, Suda, Daijee and Sama Daijee are the most urbanized market centers in the municipality. Urban settlement is developing and growing in the linear patterns along the both side of the east-west highway. Pipalthala, Jadepani, Bhamka, Shantipur, Chhela, Baitada, Musepaani, Dhursuwa, Gaujee, Bhasi, Chatahari are other settlements in the municipality (Bedkot Municipality, 2074).

The municipality falls in the Tarai physiographic region and extended up to the foot hills of Siwalik region. Elevation of the municipality ranges from $192 \mathrm{~m}$ to $1401 \mathrm{~m}$ above mean sea level. The climatic condition of this municipality is sub-tropical monsoon type. Radha Nadi, Sukha Nadi, Pipalthala Nadi, Saj Khola, Chulu Khola, Tatapani Khola, Bachhela Khola, Chunapur Khola and Bauji Khola are main rivers and streams in the municipality. These drain the Siwalik and Bhabar and flow down to the south with increasing flash flood. Since they flow from the steep slope of the Siwalik, they are capable to generate huge sediment load to the south to affect lives and properties there. 


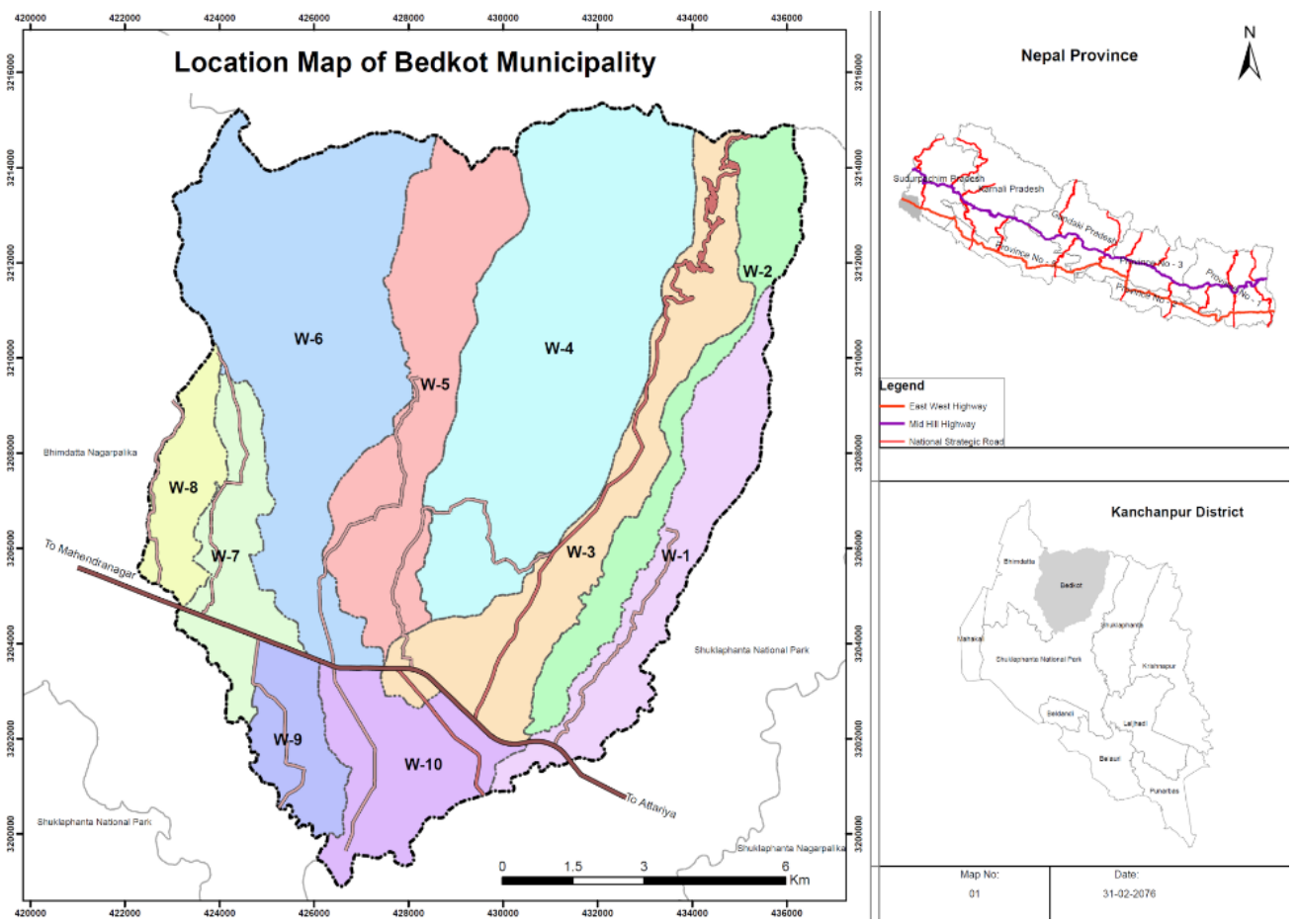

Figure 1: Location map of Bedkot municipality

\section{Methods and materials}

This paper is based on both primary and secondary data. All the data and information were collected through fieldwork in 2018 during detail consultation meetings at municipal and ward level in different stages for updating of base map. Spatial changes and transfermation of land use were also observed by transect walk in the municipality covering entire potential sites and growing nodes. Similarly, interaction with local communities were also conducted at different communities to identify spatial coverage, growth and trend of spatial expansion and development. Land use map was prepared based on $0.5 \mathrm{~m}$ spatial resolution satellite imagery. Land use data for past was collected from ICIMOD Geo-data portal and processed by using the ARC GIS 10.4 software. Changes on land use within the time period of 8 years is analyzed by overlaying it on GIS environment. Baseline infromation was acquired from Bedkot Municipality profile, 2017. 


\section{Result and discussion}

\section{Demographic Situation}

Bedkot Municipality has 62,791 population with an average household size of 5.9. Population density of the municipality is 361.6 persons per sq. km (Bedkot Municipality, 2017). In the past, the municipality had 49,479 population with average household size 5.4 (CBS, 2011). Average annual population growth rate (4.4\%) in the period between 2011 and 2017 B.S. has been calculated by using exponential population growth method. If the population growth rate remains same, the population of Bedkot municipality would be 79,265 in 2021, and 126,314 in the next 15 year (2031).

Table 1: Population distribution and growth rate by wards and gender

\begin{tabular}{|c|c|c|c|c|c|c|c|c|c|}
\hline \multirow{3}{*}{$\begin{array}{c}\text { Ward } \\
\text { no }\end{array}$} & \multicolumn{4}{|c|}{2011} & \multicolumn{4}{|c|}{2017} & \multirow{3}{*}{$\begin{array}{c}\text { Population } \\
\text { Growth } \\
\text { rate }\end{array}$} \\
\hline & \multirow[b]{2}{*}{ HH } & \multicolumn{3}{|c|}{ Population } & \multirow[b]{2}{*}{ HH } & \multicolumn{3}{|c|}{ Population } & \\
\hline & & Male & \begin{tabular}{|l|} 
Female \\
\end{tabular} & Total & & Male & Female & Total & \\
\hline 1 & 693 & 1,737 & 2,020 & 3,757 & 791 & 2436 & 2292 & 4728 & 4.3 \\
\hline 2 & 731 & 1,878 & 2,074 & 3,952 & 846 & 2661 & 2409 & 5070 & 4.7 \\
\hline 3 & 471 & 1,242 & 1,383 & 2,625 & 521 & 1619 & 1571 & 3190 & 3.6 \\
\hline 4 & 868 & 2,135 & 2,513 & 4,648 & 929 & 3121 & 2907 & 6028 & 3.9 \\
\hline 5 & 1,027 & 2,716 & 2,789 & 5,505 & 930 & 2978 & 2795 & 5773 & 0.8 \\
\hline 6 & 741 & 2,089 & 2,181 & 4,270 & 832 & 2491 & 2336 & 4827 & 2.2 \\
\hline 7 & 1275 & 3126 & 3388 & 6514 & 1685 & 4324 & 4037 & 8361 & 4.7 \\
\hline 8 & 707 & 1,725 & 1,955 & 3,680 & 889 & 2611 & 2401 & 5012 & 6.0 \\
\hline 9 & 774 & 1,988 & 2,223 & 4,211 & 938 & 2725 & 2548 & 5273 & 4.2 \\
\hline 10 & 1257 & 3272 & 3560 & 6832 & 1433 & 4771 & 4280 & 9051 & 5.4 \\
\hline Total & 9,219 & 23,492 & 25,987 & 49,479 & 10629 & 28304 & 26258 & 62791 & 4.4 \\
\hline
\end{tabular}

Source: CBS, 2011; Bedkot Municipality Profile, 2017

Bedkot presents heterogeneous population distribution and growth rate among the wards. Population density poses highest in ward number 7, 8, 9 and 10 whereas ward number 4, 5 and 6 have lowest population density ranging from 1006 to 146 per square $\mathrm{km}$ (Figure 2). Looking at ward-wise population growth rate, ward number o 8 had highest population growth rate with annual $6 \%$ then followed by ward number 10, 2 and 7 with annual growth $5.4 \%$ and $4.7 \%$ respectively (Table 1 ). This indicates that these wards pose highest population growth rate with possibility of high population concentration in the future with a demand of plan interventions. 


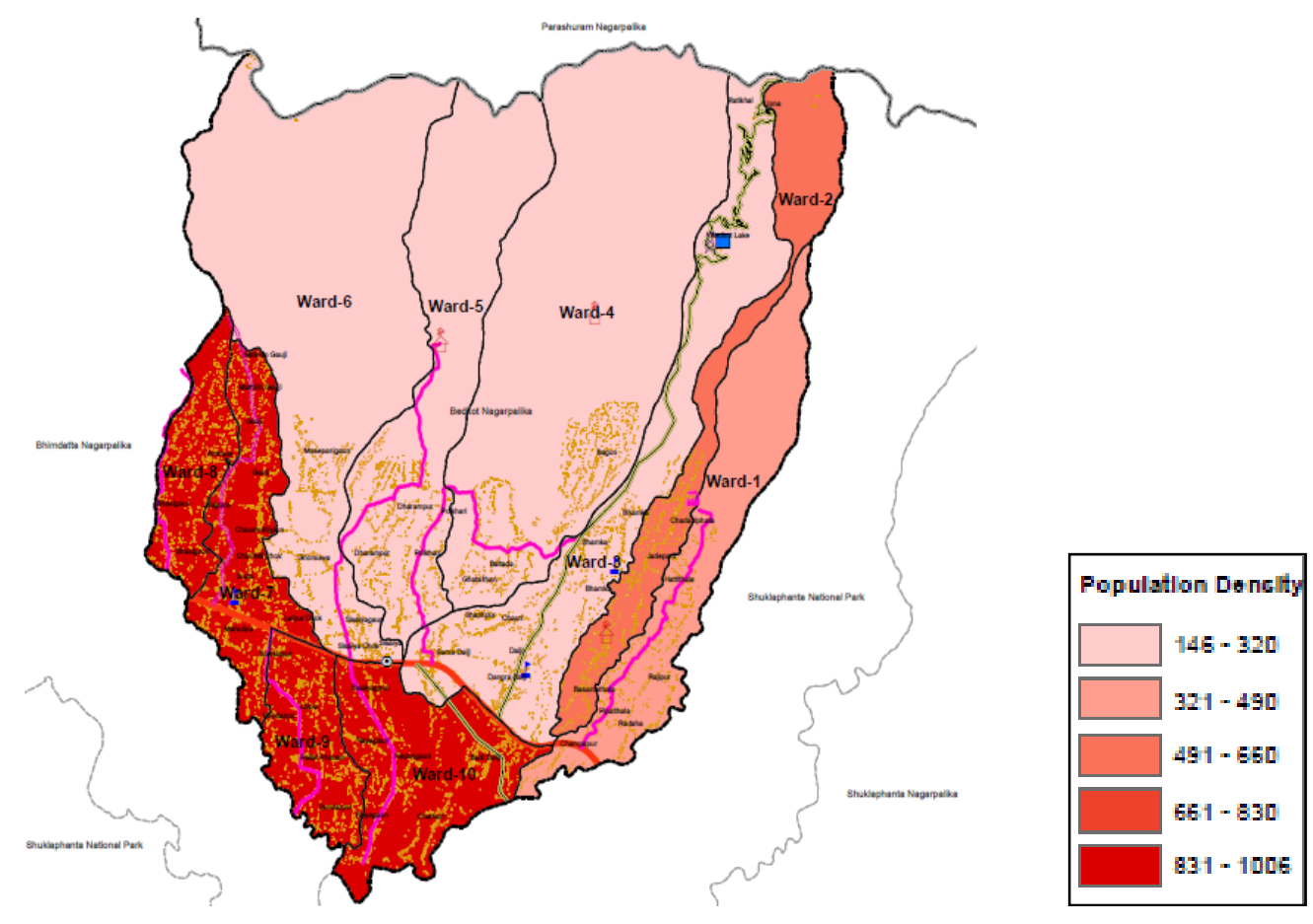

Figure 2: Population density in Bedkot municipality

With increasing trend of in-migration flow and incremental growth of goods and services in the municipality, many people have been choosing Bedkot as a best destination for lives and livelihood due to its well connectivity and nearness to India and other major cities of Nepal. Similarly, relatively cheap land value, suitable location and probable employment opportunities in future are other factors that would lead to attraction of people in Bedkot. According to key respondents of Focus Group Discussion (FGD), it was found that people from the northern hill districts and the municipalities/rural municipalities have selected Bedkot as the better place for in-migration. As of municipal profile 2017 , more than $36 \%$ families/households living in the Bedkot municipality were migrated from other districts in the past. Those people who were migrated in the municipality, about $80 \%$ were chosen the place for better livelihood. In addition, $11 \%$ were migrated due to social causes and about $7 \%$ were migrated in the municipality for the better education. There are other families who were migrated in the Bedkot municipality for business purpose and some were migrated due to conflict in the past. 


\section{Land Use and Urbanization}

Bedkot municipality covers a total of $159.42 \mathrm{Sq}$. km of land. Forest is the dominant land use and its coverage is 86.01 sq. $\mathrm{km}$ with $53.95 \%$ share of the total areal extent of the municipality. Similarly, agricultural area covers $52.1 \mathrm{sq} . \mathrm{km}$ (32.68\%). Likewise, riverine area covers 8.34 sq. $\mathrm{km}(5.23 \%)$ while built-up area is $7.94(4.98 \%)$ of the municipality.

The agricultural land use pattern of the Bedkot municipality has been categorized as Tarai cultivation based on the physiographic region. Since the municipality has dominant land cover of agriculture and forest, these areas are in pressure of changes, possibly converted into residential as the municipality has been receiving huge number of in-migrants from other districts, nearby rural areas, municipalities and towns. These lead not only the pressure on agriculture and forest land but also to give attention on preservation of environment, planed settlement development and management of the city with provision of infrastructures.

East-west highway has crossed in the middle part of the municipality, whereas, DaijeeJogbudha (Strategic road) connect to the north-south hill and Tarai districts lying on the eastern side of this municipality. Except few, many areas of the municipality have rural character, and have dispersed settlements. Dispersed settlements are ones where the houses are spread out over a wide area. They are often the homes of farmers and can be found in rural areas. Settlements like Sirsaiya, Beldandi, Lalpur, Daijee and Bhasi are developed in the linear pattern and in the compact form. These are small market centers of the municipality where most of the urbanization seems to be concentrated in future. These markets are providing services to surrounding settlements and villages. The municipality is well connected by blacktop and graveled roads which connects Mahendranagar in the west, (the district headquarter) to Attariya and Dhangadi in the east. Roads connected Daijee to Jogbuda (Dadeldhura) is also all-weather road. Present land use with road network of Bedkot municipality is presented in the Figure 3.

\section{Land Use/Land cover Change}

Land use of Bedkot Municipality is observed significant changes during the period of 2010 and 2018. Agriculture, forest, built-up area (market center including residential units, factories, schools, health post etc.) and barren land (along the river side) are dominant land use categories in the municipality. Agriculture, forest, built-up (residential area, institutional and industrial area) have been found notably changed. Agriculture practices, in general, have been found slowly decreasing due to increasing human settlements and market centers along the main roads, road junctions and bus stations. 

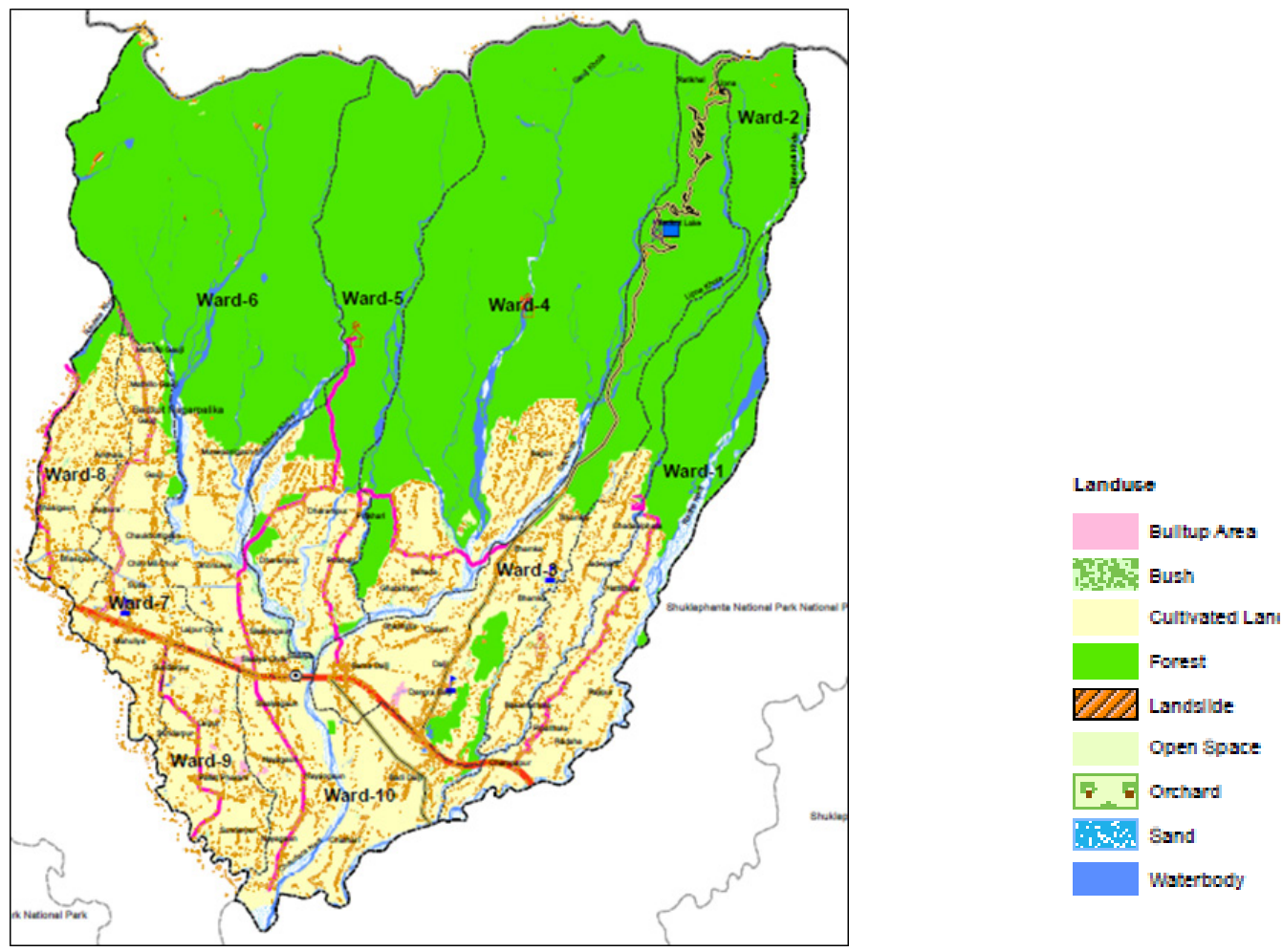

Figure 3: Present land use of Bedkot municipality

This is the case in and around Sirsaiya, Lalpur, Daijee, Beldandi chowk areas. Daijee, Sama Daijee, Beldandi, Sirsaiya, and Lalpur are local market centers as well, and growing rapidly in the recent years. Forest area is also converted into agriculture and settlement area due to the encroachment of forest as squatter settlement and agriculture. Table 2 shows the overall land use changes in Bedkot municipality whereas figure 4 shows the changes in agriculture, forest, built-up area over the period between 2010 and 2018.

Table 2: Land use/land cover changes (2010-2018)

\begin{tabular}{|c|c|c|c|c|c|}
\hline \multirow[b]{2}{*}{ Land Use Category } & \multicolumn{2}{|c|}{ Land Use 2018} & \multicolumn{2}{|c|}{ Land Use 2010} & \multirow[b]{2}{*}{ Change } \\
\hline & $\begin{array}{c}\text { Area } \\
(\mathrm{sq} \mathbf{k m})\end{array}$ & Percent & $\begin{array}{c}\text { Area } \\
(\mathrm{Sq} \mathrm{km})\end{array}$ & Percent & \\
\hline Cultivated Land & 52.10 & 32.68 & 57.71 & 36.2 & -3.52 \\
\hline Forest & 86.01 & 53.95 & 88.02 & 55.21 & -1.26 \\
\hline
\end{tabular}




\begin{tabular}{|l|r|r|r|r|r|}
\hline Water body & 2.74 & 1.72 & 4.97 & 3.12 & -1.4 \\
\hline Sand & 5.60 & 3.51 & 5.74 & 3.60 & -0.09 \\
\hline Built-up Area & 7.94 & 4.98 & 2.22 & 1.39 & 3.59 \\
\hline Landslide & 0.14 & 0.09 & 0.35 & 0.22 & -0.13 \\
\hline Open Space & 0.06 & 0.04 & 0.33 & 0.21 & -0.17 \\
\hline $\begin{array}{l}\text { Others (Bush, grassland, } \\
\text { Orchard etc) }\end{array}$ & 4.83 & 3.03 & 0.08 & 0.05 & 2.98 \\
\hline Total & $\mathbf{1 5 9 . 4 2}$ & $\mathbf{1 0 0 . 0 0}$ & $\mathbf{1 5 9 . 4 2}$ & $\mathbf{1 0 0 . 0 0}$ & \\
\hline
\end{tabular}

Source: ICIMOD, 2010 and IUDP, 2018; field verification, 2018

While comparing the conversion of land cover between 2010 and 2018, following scenario (Table 4) has been observed. The data was derived by analyzing in GIS environment to look at the conversion of land use in the period of 8 years. It has been found that conversion of land use from agriculture to built-up and forest to agriculture and residential is significant. Comparing the data, cultivation area has been found converted into built-up, forest, open spaces and sand. Similarly, forest area has been found converted into built-up, cultivation, bush, open space, orchard, sand and land slide. It is also found that sandy area has also been converted into cultivation, bush, forest and water body.

Table 3: Summary of the percentage of area converted into different land uses 2010-2018

\begin{tabular}{|c|c|c|c|c|c|c|c|c|c|}
\hline $\begin{array}{l}\text { S. } \\
\text { No. }\end{array}$ & $\begin{array}{l}\text { Land Use } \\
\text { Category }\end{array}$ & 窇 & 苞 & 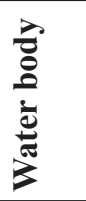 & : & 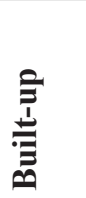 & 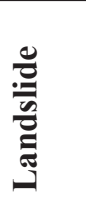 & 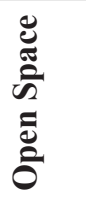 & ذ্ّ \\
\hline 1 & $\begin{array}{l}\text { Cultivated } \\
\text { Land }\end{array}$ & 31.56 & 0.17 & - & - & 2.48 & - & - & 1.78 \\
\hline 2 & Forest & 1.12 & 53.65 & - & - & 1.09 & - & - & 0.30 \\
\hline 3 & Water body & - & - & 1.72 & 1.11 & - & - & - & 0.67 \\
\hline 4 & Sand & - & - & - & 2.22 & - & - & - & 0.23 \\
\hline 5 & Built-up Area & - & - & - & - & 1.41 & - & - & 0 \\
\hline 6 & Landslide & - & 0.13 & - & - & - & 0.09 & - & 0 \\
\hline 7 & Open Space & - & - & - & - & - & - & 0.04 & 0 \\
\hline 8 & Others & - & - & - & - & - & - & - & 0.05 \\
\hline & Total & 32.68 & 53.95 & 1.72 & 3.51 & 4.98 & 0.09 & 0.04 & 3.03 \\
\hline
\end{tabular}

Source: Calculated based on ICIMOD, 2010 and IUDP GIS Database, 2018 
Table 3 reveals the result of land use changes of Bedkot municipality overlaying 2010 to 2018 land use data on the GIS environment. It shows that agricultural land is converted into built-up, forest and others (road, institutional, industrial area etc.) whereas forest land is converted into cultivation, built-up and others. Similarly, some area of water converted into sand and others.

Land use changes of Bedkot Municipality indicates a variety of complex problems in land use planning. The majority of the problems in the municipal area can be categorized into natural and anthropogenic. With regard to the natural aspect, due to erosion/side cutting and flooding there has been brought significant changes in land use and land cover particularly along the river side. In anthropogenic aspect, the cultivable area has been converted into built- up area i.e. expansion of market area, introducing new residential buildings, roads etc. Linear and cluster settlements have been observed in many areas of the municipality. Brick factories in Suda and Daijee area and increasing small scale industries have also brought significant changes that reduces the agriculture land. Generally four major factors have been identified in connection to the land use change in the municipality. These findings have been identified on the basis of present land use scenario, land use change trend analysis, field observation, community consultations and municipal interaction.

Agriculture land has been converted into built-up area: This is because of the increasing residential building/commercial units around the market centers and factories. These scenarios have observed in and around Daijee, Chhela, Lalpur and Sirsaiya. Changes have also been observed along the east-west highway and, Shantipur road and DaijeeBedkot taal road corridors.

Forest and forest encroachment: Many areas of the municipality are under the forest; and encroachment were found high after 2040 BS. Mostly the people evacuated from the Suklaphata Wildlife Reserve, flood victims and landless people are occupying the forestland. Besides, the land allocation to freed bonded labors (Mukta-Kamaiya) has been shown the forest land use change in Daijee and Suda area. The forestland of $2.3 \mathrm{sq}$. $\mathrm{km}$ has been allocated to 1409 households of freed bonded labor. At the same time, in the course of different time period a total of 2106 households have encroached $12.1 \mathrm{sq} . \mathrm{km}$ of forest land in different locations of the Suda and Daijee area (NLUP, 2015). However, forest area during the period is also found converted into agriculture and residential area. This is due to high rate of in migration and increase of informal settlements. 
River and waste land: Rivers originated from the Chure/Siwalik regions are flowing by making wide channel. Every summer these river are flooded and local people looses their properties as a result of side cutting, sedimentation and inundation.

Market center: Particularly Daijee, Bachhela, Lalpur, Sirsiya market expansion is taking place in terms of functional range and magnitude. Gravity of these markets are increasing, and in migration has also been increasing from the last 8 years and people particularly from the northern hill districts are attracted to settle around Daijee and Suda which is also brought significant changes in land use.
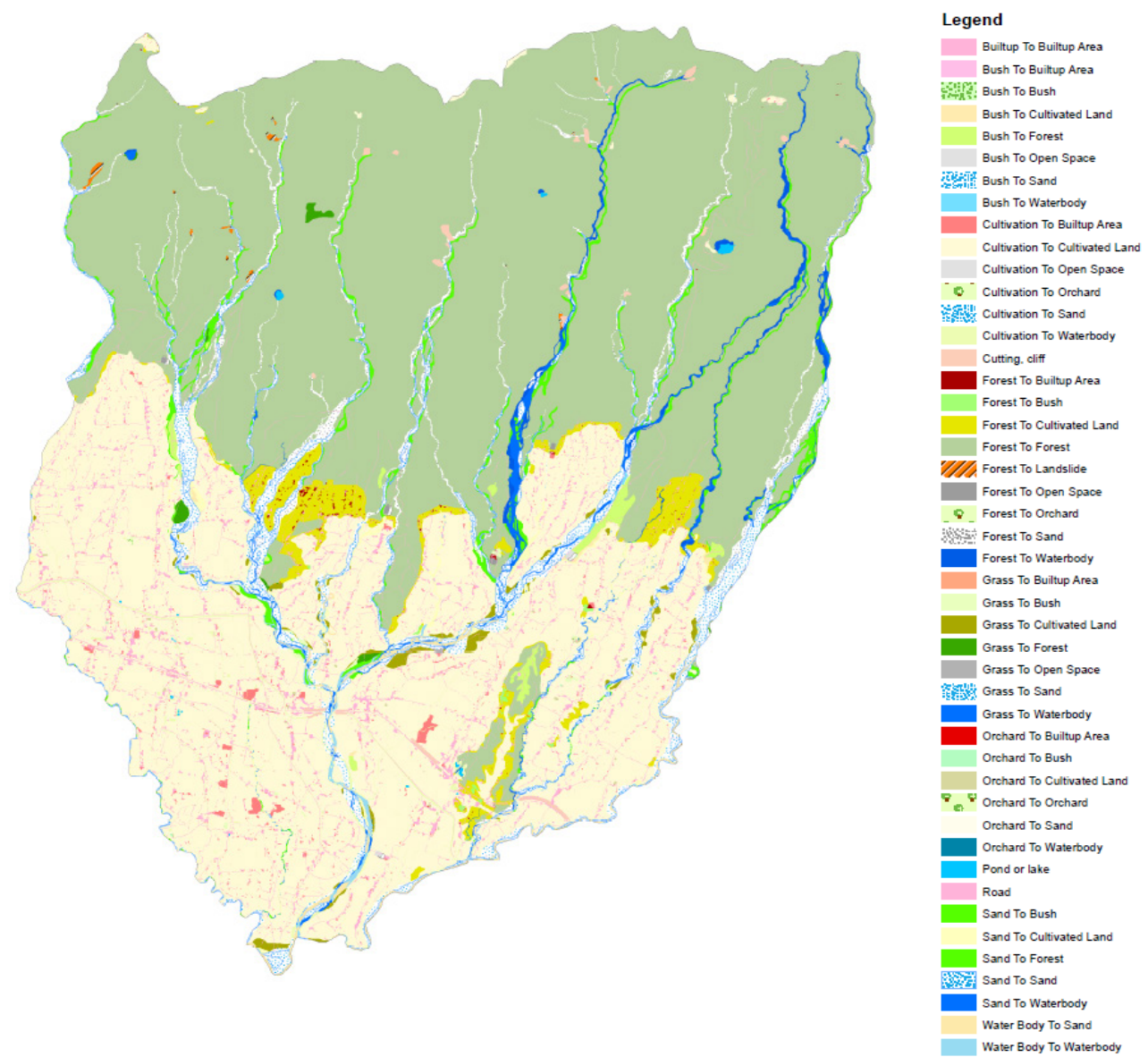

Figure 4: Land use changed observed in 2010-2018 in Bedkot municipality 


\section{Spatial expansion and implications in spatial planning}

Having both scattered and compact settlements, Bedkot municipality poses spatial dynamics of urban landscape. Settlements in the municipality except of highway corridor and road junctions were observed scattered. Compact settlements have also been developed along the east-west highway corridor and road junctions. Sirsaiya, Lalpur, Daijee and Sama Daijee are the most urbanized market centres in the municipality which are being developed in the linear patterns on the both sides of the east-west highway. Urban expansion seems to be developed along the Daijee-Bedkot Taal-Jogbuda road; and Shantipur road corridor area in the future. Daijee is also being developed as an entry point to Jogbuda (Dadeldhura) therefore it is expected that both residential and commercial activities will be increase; and it will be developed as a main market center. Study reveals that the population is concentrated mainly at along the east-west highway corridor, Daijee-Jogbuda road corridor, Sama Daijee, Champapur toward west that has brought a significance changes in land use and land value pattern in recent years (NLUP, 2015).

Study of changes on urban land use is associated in urban development planning, especially for providing basic infrastructures to growing population on the one hand, and management of city for its sustainability on the other. Rapid population growth leads unplanned, unsystematic urbanization which can cause profound impacts on various environmental components, especially on land and water (Patra et al., 2018). A detailed understanding of the dynamics of land use change and its implications in spatial planning is, therefore, necessary for coping with environmental changes and facilitating sustainability of the town.

One of the major component of spatial planning is land use zoning to regulate future land use. In the context of land use zoning, particularly 6 zones have been proposed for Bedkot municipality (Table 4). The land use zone is proposed based on present land use scenario, land use change trend analysis, field observation, community consultations and municipal interaction. Among them, conservation zone (Chure/forest and water body) has covered the significant percentage of area (54.12\%) whereas mixed use zone proposed along the both sides of east west highway and Daijee-Jogbuda road corridor covers 2.99 percentage. Industrial zone proposed at Chhela area as the Government of Nepal has already proposed industrial zone/Special Economic Zone (SEZ) for Far West Province covers 1.6 percentage. Similarly, flood prone area, sedimentation sites are proposed as restricted zone which covers 10.07 percentage of total area. 
Table 4: Proposed land use zone of Bedkot municipality

\begin{tabular}{|l|r|r|}
\hline \multicolumn{1}{|c|}{ Land use zone } & Area (sq. km) & \multicolumn{1}{c|}{ Percent } \\
\hline $\begin{array}{l}\text { Mixed Use (residential, } \\
\text { Commercial, Institutional) }\end{array}$ & 4.77 & 2.99 \\
\hline Residential zone & 9.45 & 5.93 \\
\hline Agriculture zone & 40.16 & 25.19 \\
\hline Industrial zone & 2.70 & 1.69 \\
\hline $\begin{array}{l}\text { Conservation (Chure/ forest, Water } \\
\text { body) }\end{array}$ & 86.28 & 54.12 \\
\hline Restricted Area (Sensitive Area) & 16.06 & 10.07 \\
\hline Total & 159.42 & 100.00 \\
\hline
\end{tabular}

Looking at the spatial expansions of Bedkot, Sama Daijee, Beldandi, Sisaiya, and Lalpur are some other few junctions and small market centres where most of the urbanization seems to be concentrated in future. Therefore, it is also expected that urban expansion will also be concentrated in and around these areas, highway/road corridor and main junctions (Figure 5). East-west highway and Daijee-Jogbuda Road corridor is a pull factor where many residential building are concentrated. Bhasi, Lalpur, Sisaiya and Daijee are being expanded rapidly and developed in the east-west highway corridor. Besides these, Bada Daijee, Sama Daijee, Champapur, Bassantathala, Pipalthala, Mahulia, Suda and Amthala are other areas to be developed in future. Daijee is also developing as an entry point to Jogbuda (Dadeldhura) whereas Suda is developed as the main commercial and the residential area of the Kanchanpur District, and located at vicinity areas of the Bhimdatta municipality. Many residential and business-industrial units are being shifted eastward particularly along the east-west highway. Therefore, the municipality has been receiving large number of migrants from the northern hill-mountain districts; and it is expected that residential, commercial and industrial activities will be rapidly increased in future. 


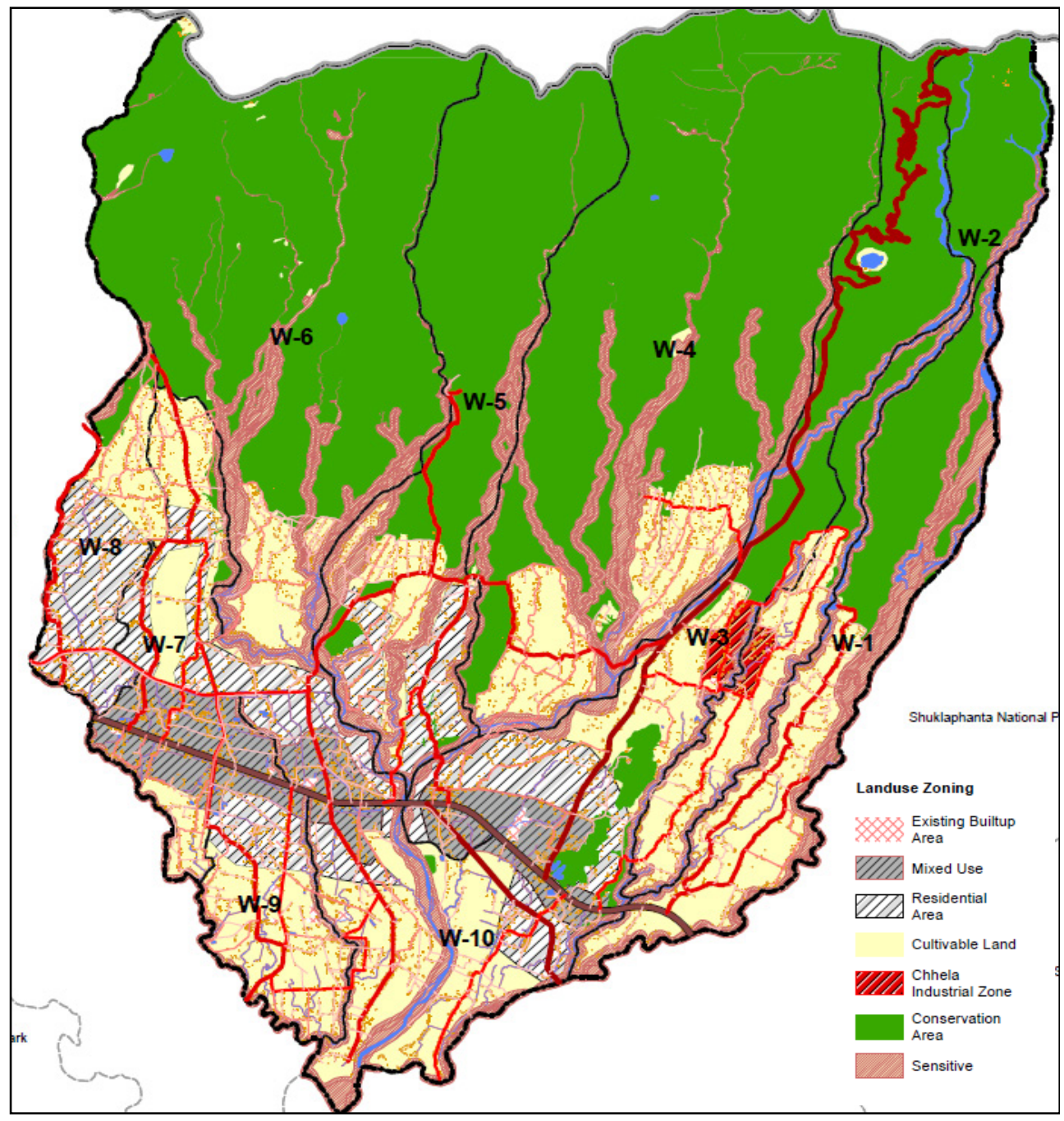

Figure 5: Spatial dimensions of urban land use zones in Bedkot municipality

\section{Conclusion}

Newly declared municipalities like Bedkot is rapidly growing and becoming a center of attraction for the people living in the surrounding areas. Such attractions have resulted rapid urbanization giving attentions to policy initiatives and planners for sustainable spatial planning. The land use changes between 2010 and 2018 in the municipality is taking place rapidly through decreasing agriculture and forest land, and converting these lands into built-up area. The data reveal that in the 8 years period of time $2.48 \%$ agriculture land has been converted into built-up area and 1.78 percent area is converted 
into road, institutions and other public infrastructures. Similarly, $1.12 \%$ forest area has been converted into cultivation and $1.09 \%$ of forest is converted into built-up area. Notable changes have also been occurred on water bodies decreasing $1.4 \%$ of its land converted into sand and bushes.

Trend of urban development and expansion of the built-up area mainly found in and around the main market centers, along the highway, feeder roads and nodal road junctions in the municipality. Spatial expansion of the urban development in the municipality is increasing haphazardly without a proper spatial planning and lacking the long-term development vision to regulate unwanted sprawl settlements. One of the best tool to regulate municipality is to implement land use planning indicating the spatial advantages of potential zones for urban development. The proposed land use zoning (mixed use, residential, agriculture, industrial, conservation and restricted area) could be used as a guiding tool of spatial planning for Bedkot municipality for long-term development which needs to be implemented by the municipality to regulate sprawal urban development.

\section{References}

Arshad, S., Malik, M., \& Malik, M. (2017). Spatial dimensions of urban Growth and land use changes in a small city of Bahawalpur District, Pakistan. Universal Journal of Engineering Science 5 (2): 17-28. Retrieved from http://www.hrpub. org/download/20170430/UJES1-1460870.pdf.

Bedkot Municipality. (2017). Municipal profile. Kahnchanpur: Bedkot Municipality.

CBS. (2011). National Population and Housing Census (Village Development Committee and Municipality. Kathmandu: Central Bureau of Statistics, Government of Nepal.

Dahal, K. \& Timalsina, K. P. (2018). Spatio-temporal Dynamics of Municipal Planning, A Case Study of Barahathawa Municipality, Nepal, South Asian Journal of Development Research. (Manuscript Accepted on 12 September, 2019). Vol (No) pp or website

DUDBC. (2018). Preparation of Integrated Urban Development Plan Bedkot Municipality. Kathmandu: DUDBC.

ICIMOD. (2010). Regional Database System. Retrieved from http://www.rds.icimod. org/Home/ DataDetail?metadataId=9224.

Patra, S., Shoo, S. \& Mahatra, S.C. (2018). Impacts of urbanization on land use / cover changes and its probable implications on local climate and groundwater 
level. Science Direct, 7 (2). PP Retrieved from https://www.doi.org/10.1016/j. jum.2018.04.006.

Pham H.M., Yamaguchi Y., Bui T.Q. (2011). A case study on the relation between city planning and urban growth using remote sensing and spatial metrics. Landscape and Urban Planning 100(3):223-30. Retrieved from https://www.researchgate. net/publication/251528042_A_case_study_on_the_relation_between_city_ planning_and_urban_growth_using_remote_sensing_and_spatial_metrics.

NLUP. (2015). Preparation of VDC level land resources maps (Present Land Use Map, Soil Map, Land Capability Map, Land Use Zoning Map and VDC Profile for Land Use Zoning Map and Superimpose of Cadastral Layers), Data Base and Reports (package-5). Kathmandu: National Land Use Project.

UN. (1974). Methods for projections urban and rural population. New York, UN. Retrieved from https://www.un.org/en/development/desa/population/ publications/manual/projection/urban-rural.asp.

World Bank. (2013). Urban growth and spatial transition in Nepal, An Initial Assessment. Manual VIII. Washington DC: World Bank. 